\title{
The Usefulness of Endoscopic Retrograde Cholangiopancreatography at Preoperative or Postoperative Cystic Echinococcus Patients
}

\author{
Preoperatif veya Postoperatif Kistik Echinococcus Hastalarında Endoskopik Retrograd \\ Kolanjiyopankreatografinin Faydası
}

\author{
(D) Ekrem Çakar, (1) Hasan Bektaş
}

University of Health Sciences Turkey, İstanbul Training and Research Hospital, Clinic of General Surgery, İstanbul, Turkey

\begin{abstract}
Introduction: The aim of this study was to evaluate the efficacy of endoscopic retrograde cholangiopancreatography (ERCP) at cystic echinococcus (CE) patients in the preoperative or postoperative period.

Methods: Hepatic CE patients who underwent ERCP due to jaundice, bile leakage and rupture of the cyst to biliary tract between January 2010 and January 2018 were retrospectively evaluated in the study. Clinical status of the patients, ERCP, operation and radiology reports, and blood tests were assessed through hospital records and ERCP techniques, and ERCP success, complications and clinical situations of patients were noted.

Results: A total of 63 patients who participated in the study had 71 ERCP procedures and the mean age of the patients was $46.49 \pm 18.33$ years and the W/M ratio was $31 / 32$. ERCP were performed due to icter, bile leakage and opening to biliary tract at 38.28 and five patients respectively. Sphincterotomy and balloon application is the most frequently applied procedure in 40/71 patients. The mean time of closure of the bile leakage after ERCP was $19.29 \pm 10.64$ days. ERCP was not successful in $4 / 63$ patients (6.3\%).

Conclusion: ERCP can be safely and successfully used for both diagnostic and therapeutic purposes in CE patients and CE complications.

Keywords: Cystic echinococcus, endoscopic retrograde cholangiopancreatography, icterus, bile leakage, magnetic resonance cholangiography, sphincterotomy
\end{abstract}

öz

Amaç: Bu çalışmanın amacı, endoskopik retrograd kolanjiyopankreatografinin (ERCP) kistik ekinokok (KE) hastalarında preoperatif veya postoperatif dönemde etkinliğini değerlendirmektir.

Yöntemler: Ocak 2010-Ocak 2018 tarihleri arasında sarılık, safra kaçağı ve kistin safra yoluna rüptürü nedeniyle ERCP yapılan karaciğer KE hastaları retrospektif olarak çalışmaya dahil edildi. Hastaların klinik durumları, ERCP, operasyon ve radyoloji raporları, kan testleri hastane kayıtları ve ERCP teknikleri ile değerlendirildi, ERCP başarısı, komplikasyonlar ve hastaların klinik durumları kaydedildi.

Bulgular: Çalıșmaya katılan toplam 63 hastaya toplam 71 ERCP prosedürü uygulandı ve hastaların ortalama yaşı 46,49 $\pm 18,33$ yıl ve K/E oranı 31/32 idi. ERCP sırasıyla 38, 28 ve 5 hastada ikter, safra kaçağı ve safra yollarına açılma nedeniyle uygulandı. Sfinkterotomi ve balon uygulaması 40/71 hastada en sık uygulanan işlemdir. ERCP sonrası safra kaçağının ortalama

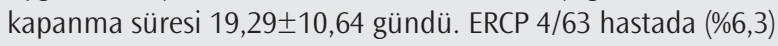
bașarılı olamadı.

Sonuç: ERCP, KE hastalarında ve KE komplikasyonlarında hem tanı hem de tedavi amacıyla güvenle ve başarılı bir şekilde kullanılabilir.

Anahtar Kelimeler: Kistik ekinokok, endoskopik retrograd kolanjiyopankreatografi, ikter, safra kaçağı, manyetik rezonans kolanjiyografi, sfinkterotomi

\section{Introduction}

Cystic echinococcus (CE) is a disease caused by various species of the parasite echinococcus whose endemic range extends from South America to Africa and Eurasia (1-4). Being an endemic country, approximately 4,000 new cases are reported each year in Turkey (5). Though it is most frequently found in the liver, CE can affect many organs in the body. The complications of the disease can be life-threatening, with a $2-4 \%$ mortality rate $(6,7)$. Diagnosis is usually incidental (8), as disease progression is slow in general.

In addition to incidental diagnosis in asymptomatic patients, CE can be diagnosed after the onset of symptomatic complications. The most common complications are allergic reactions due to cyst 
rupture, secondary infection of the cyst and jaundice with or without accompanying cholangitis due to the compression of the biliary tract by the cyst or by intrabiliary rupture. Among these complications, rupture of the cyst into the bile ducts is the most common, seen in $2-42 \%$ of the patients (9). Such cysts are usually located in the right lobe of the liver and can cause complications such as cholecystitis, cholangitis, liver abscess, sepsis and pancreatitis $(9,10)$.

Once definitive diagnosis is made for $\mathrm{CE}$, medical, percutaneous and surgical treatment methods are available (4). Endoscopic retrograde cholangiopancreatography (ERCP) is an appropriate diagnostic and therapeutic modality that can be used both preoperatively for cysts opening into the biliary tract and for the management of postoperative complications such as bile fistulae and jaundice (9). In this study, we examined patients who underwent ERCP due to CE in the preoperative or postoperative period and evaluated the efficacy of ERCP.

\section{Methods}

Data for the study were collected retrospectively from patient records. Ethics Committee Approval was obtained of by the University of Health Sciences Turkey, İstanbul University Training and Research Hospital (decision no: 2018, date: 11.10.2019) and informed consent from all patients were obtained. The study population consisted of patients who underwent ERCP because of liver CE between January 2010 and January 2018. Patients with bile leak due to bile duct injuries or jaundice associated with the obstruction of the common bile duct were excluded from the study. Hospital records of the patients were screened for demographic data, clinical conditions, endoscopic and surgical procedures, laboratory tests and imaging studies. Patients with incomplete records were also excluded from the study.

\section{Statistical Analysis}

Statistical analysis was performed with the IBM ${ }^{\circledR}$ SPSS ${ }^{\circledR}$ Statistics Version 21 (IBM, New York, USA) computer software. Normally-distributed continuous variables were expressed as mean \pm standard deviation (SD) and variables without normal distribution were expressed as median and ranges. Paired t-test and Wilcoxon test were used for the comparison of numerical dependent variables between two groups. One-way ANOVA test was used to compare multiple groups. P value $<0.05$ was defined as indicating statistical significance.

\section{Results}

A total of 63 patients were included in the study, of which 31 were female and 32 were male. The mean age $( \pm$ SD) of the patients was $46.49 \pm 18.33$ years. The total number of ERCP procedures performed was 71. Thirtyfour of these were performed in the postoperative period and 37 either preoperatively or on patients who were not operated. Regarding the indications, 38 procedures were performed because of biliary obstruction either before or after the operation, 28 were performed postoperatively because of bile leakage, and 5 were performed before surgery because of magnetic resonance cholangiopancreatography (MRCP) findings revealing communication between the cysts and the biliary tract. The mean duration between surgery and ERCP was 15.62 \pm 16.12 (6-90) days.

Majority of the patients (49 of the 63 total) had cysts in the right lobe of the liver. Only eight patients had cysts in the left lobe whereas in six patients, both lobes contained echinococcus cysts.

Table 1 lists the therapeutic procedures performed during ERCP for each ERCP indication. The most common procedure was sphincterotomy and balloon application, performed in 40 of the 71 ERCP procedures.

The mean diameter of the common bile duct was $10.19 \pm 4.44 \mathrm{~mm}$ as measured by ERCP. When calculated separately for each indication, the mean diameter of the common bile duct for biliary obstruction, bile leakage and preoperative diagnosis of intrabiliary rupture were $12.79 \pm 3.88 \mathrm{~mm}, 7.16 \pm 3.04 \mathrm{~mm}$ and $7 \pm 1.87 \mathrm{~mm}$, respectively. Patients with biliary obstruction had a significantly more dilated common bile duct compared to the other patients $(p<0.001)$.

Of the 27 patients who had surgery for CE followed by ERCP, 22 had endocystectomy with capitonnage; 3 had puncture, aspiration, injection and reaspiration, and 2 had endocystectomy with partial pericystectomy and omentoplication.

Levels of total and direct bilirubin, gamma-glutamyl transferase and alkaline phosphatase before and after the ERCP procedures were compared and a statistically significant decrease after ERCP was found in all 4 parameters ( $p<0.001$ for all variables) (Table 2$)$.

Eight patients required ERCP to be performed twice because of incomplete success in the first attempt. Of these, 4 patients had bile leakage after surgery, 3 had obstructive jaundice in the postoperative

Table 1. Distribution of therapeutic procedures performed during endoscopic retrograde cholangiopancreatography for each endoscopic retrograde cholangiopancreatography indication

\begin{tabular}{|c|c|c|c|}
\hline \multirow[b]{2}{*}{ ERCP procedures } & \multicolumn{3}{|l|}{ Indications for ERCP } \\
\hline & Biliary obstruction (n) & Bile leakage (n) & $\begin{array}{l}\text { Radiological findings suggesting } \\
\text { intrabiliary rupture ( } \mathrm{n} \text { ) }\end{array}$ \\
\hline Sphincterotomy alone & 1 & 0 & 1 \\
\hline Sphincterotomy and biliary stent & 5 & 10 & 0 \\
\hline Sphincterotomy and hydatic membrane extraction & 1 & 3 & 0 \\
\hline Balloon application and biliary stent & 4 & 4 & 0 \\
\hline Sphincterotomy and pus drainage & 0 & 0 & 0 \\
\hline Sphincterotomy, hydatic membrane extraction and pus drainage & 3 & 0 & 0 \\
\hline Sphincterotomy and balloon application & 24 & 11 & 4 \\
\hline
\end{tabular}

ERCP: endoscopic retrograde cholangiopancreatography 


\begin{tabular}{|l|l|l|l|}
\hline \multicolumn{1}{|c|}{ Table 2. The comparison of laboratory findings before and after the endoscopic retrograde cholangiopancreatography procedures } \\
\hline & Before ERCP & After ERCP & p \\
\hline Total bilirubin (mg/dL) (mean \pm SD) & $3.62 \pm 3.17$ & $1.18 \pm 0.69$ & $<0.001$ \\
\hline Direct bilirubin (mg/dL) (mean \pm SD) & $2.31 \pm 2.29$ & $0.65 \pm 0.43$ & $<0.001$ \\
\hline GGT (U/L) (mean \pm SD) & $272.26 \pm 244.1$ & $119.25 \pm 74.09$ & $<0.001$ \\
\hline ALP (U/L) (mean \pm SD) & $228.47 \pm 161.07$ & $109.12 \pm 71.2$ & $<0.001$ \\
\hline
\end{tabular}

ALP: alkaline phosphatase, GGT: gamma-glutamyl transferase, ERCP: endoscopic retrograde cholangiopancreatography

period, and 1 had obstructive jaundice in the preoperative period. The mean duration for the closure of biliary fistula after ERCP was $19.29 \pm 10.64$ days ranging from 3 to 50 days.

As complications of the ERCP procedure, three patients developed mild to moderate pancreatitis that was treated conservatively. ERCP was not successful in 4 of the 63 patients (6.3\%). Three of these 4 patients underwent ERCP because of postoperative bile leakage and 1 because of obstructive jaundice in the postoperative period. Surgical intervention was the treatment of choice in case ERCP was not successful. For the patients with bile leakage, the bile ducts communicating with the cyst were ligated, with common bile duct exploration and repair over T-tube added in one patient. In a patient with obstructive jaundice, bile duct exploration and T-tube drainage were performed.

\section{Discussion}

CE most commonly infects the liver and although the disease progresses slowly and insidiously, it may have various acute complications such as jaundice and cholangitis as a result of external compression or rupture into the bile ducts due to the elevated pressure in the cyst during growth (9). Intrabiliary cyst rupture is the most common complication, with rates reported as high as $42 \%$ in some series $(9,11)$.

The communication between the cyst and the biliary tract can be classified as major and minor communications. Minor communications are usually not detectable in the preoperative period. They do not cause any symptoms preoperatively but might result in bile leakage in the postoperative period. Conversely, major communications are observed in $3-17 \%$ of CE patients and are usually diagnosed preoperatively. Obstructive jaundice, biliary colic, cholangitis, liver abscesses, sepsis and anaphylaxis are possible complications that can develop in the preoperative period due to the passage of the cystic content into the bile ducts $(9,12,13)$.

ERCP has many uses in CE patients, including treatment of preoperative or postoperative biliary obstruction, treatment of biliary fistulae, prophylactic preoperative endoscopic sphincterotomy to prevent bile leakages in the postoperative period, and as a preoperative diagnostic tool (13-15).

However, the routine use of prophylactic endoscopic sphincterotomy (ES) for uncomplicated CE is not universally accepted. While some authors support the routine use of preoperative ERCP for prophylactic ES to reduce postoperative complications in uncomplicated cysts, others recommend that the preoperative use of ERCP is restricted to diagnostic purposes in demonstrating the anatomy of the bile ducts and their relationship with the cysts $(9,14,16,17)$. Also of note is that the increasingly widespread use of MRCP provides a non-invasive alternative to ERCP for diagnostic purposes without the risk of potentially severe complications related to $\operatorname{ERCP}(9,18)$. In our study, MRCP was performed preoperatively in all patients and prophylactic ERCP for ES was performed in only five patients for whom rupture of the cyst into the biliary tract was radiologically demonstrated. Some studies showed that ERCP was used even in routine procedure to reduce post-operative complications. Bile fistulae can be observed in patients, and some of the fistulae will close spontaneously even though ES has not been performed $(9,16)$.

The reported success rate of ERCP in the treatment of biliary obstructions observed in cholangiography prior to CE surgery is $80-100 \%$ $(9,19)$. Sphincterotomy, extraction of cystic content using balloon or basket catheters, nasobiliary drainage and biliary stenting are possible treatment options. In our study, the complaints of all 31 patients with biliary obstruction were resolved after ERCP was performed preoperatively.

ERCP is an effective method for the treatment of obstructive jaundice and biliary fistulae which are the most common complications in the early postoperative period of CE surgery $(5,11,14,20,21)$. ES alone is usually not adequate for the treatment of obstructive jaundice; extraction of cystic contents from the common bile duct and even biliary stenting might be necessary (22). One study reported the management of seven patients with CE developing obstructive jaundice and cholangitis after surgery, who were treated by ERCP. Within 36 hours of ES and clearing of the biliary tract of debris, normal bile flow was achieved and symptoms related to biliary obstruction were resolved (23). In our series, ERCP was performed in three patients in the postoperative period for biliary obstruction. Two of the patients were successfully treated by ES and extraction of cystic contents while the third patient underwent surgery because of failure of endoscopic treatment.

Bile leaks are encountered more frequently in the early postoperative period, with the output decreasing after the 10th postoperative day. However, it is difficult to consistently predict whether the leakage will continue or not. A biliary fistula with high output which is not steadily decreasing rarely closes spontaneously $(24,25)$. In our series, ERCP for bile leak was performed for 27 patients, of whom 8 were within the first 10 days of the postoperative period as the output of leakage was high and spontaneous closure was not anticipated.

Surgery has traditionally been the standard treatment of fistulae not closing spontaneously. Thanks to advances in the field of endoscopic procedures, ERCP has become the first line treatment as it is not hindered by the difficulties of redo surgery such as adhesion and inflammation of tissues in the surgical field $(17,26)$. The mechanism 
of action of ERCP in treating biliary fistulae is to reduce the pressure in the bile ducts, which directs the bile flow to the duodenum and accelerates spontaneous closure $(20,27,28)$. Delay in performing ERCP in high-output fistulae may result in infectious complications and cause the fistulae to become chronic $(24,25)$. The success rate of ERCP in the treatment of biliary fistulae has been reported as high as $90 \%$ (14). Numerous studies in the literature have reported spontaneous closure of biliary fistulae after ERCP within 3 to 43 days $(29,30)$. One study has reported that all cases of biliary fistulae were closed within 26 days following ES (14). In another study, a total of 46 ERCPs were performed on patients who were operated for CE and who developed postoperative biliary leakage. All cases of biliary leakage ceased in 2-21 days. The most commonly performed procedure in that study was ES (23). In our study, bile leaks were closed in an average of 19 days after ERCP, which is consistent with the literature. While ES was the most frequent procedure among ERCPs performed for postoperative bile leaks, which is in parallel with the literature, our series differed in that ES was combined with other procedures. We believe that combining ES with other procedures might be useful in avoiding the requirement for additional ERCPs due to inadequate treatment by ES alone. In addition, surgical treatment for biliary leakage was needed in three patients (12.5\% of the total 24$)$ as ERCP was not successful.

\section{Conclusion}

For the management of CE patients, ERCP is a useful tool for intrabiliary rupture of cysts used in the preoperative period for both diagnostic and therapeutic purposes. It is also an effective method for the treatment of biliary obstruction and bile leaks in the postoperative period, which can avoid unnecessary surgery. MRCP is a safe and viable alternative to ERCP for the diagnosis of minor communications between the cysts and the biliary tract which ERCP might fail to demonstrate. For patients with high-output biliary fistulae and obstructive jaundice, ES combined with biliary stenting or common bile duct exploration with a balloon catheter is effective at the preoperative and postoperative period. ERCP is a minimally invasive procedure that can be utilized safely and effectively; therefore, it should be the first line of treatment for the mechanical complications of CE.

Acknowledgements: This research did not receive any grants from funding agencies in the public, commercial, or not-for-profit sectors.

\section{Ethics}

Ethics Committee Approval: It was obtained of by the University of Health Sciences Turkey, İstanbul University Training and Research Hospital (decision no: 2018, date: 11.10.2019).

Informed Consent: Informed consent from all patients were obtained.

Peer-review: Externally peer-reviewed.

Authorship Contributions: Surgical and Medical Practices - E.C.., H.B.; Concept - E.Ç.; Design: E.C.., H.B.; Data Collection or Processing - E.Ç., H.B.; Analysis or Interpretation - E.C.., H.B.; Literature Search - E.C..; Writing: E.Ç., H.B.

Conflict of Interest: The authors declare that they have no conflicts of interest.
Financial Disclosure: The authors declared that this study received no financial support.

\section{References}

1. Eckert J, Deplazes P. Biological, epidemiological, and clinical aspects of echinococcosis, a zoonosis of increasing concern. Clin Microbiol Rev 2004; 17: $107-35$

2. Zhang W, McManus DP. Recent advances in the immunology and diagnosis of echinococcosis. FEMS Immunol Med Microbiol 2006; 47: 24-41.

3. Ișık A, Fırat D, Korkmaz S, Demiryıldız I, Yılmaz I . Atipik Prezente Kist Hidatik: Pankreas Bașında Kitle. Sakarya Tıp Dergisi . 2018;8:149-52.

4. Mihmanli M, Idiz UO, Kaya C, Demir U, Bostanci O, Omeroglu S, et al. Current status of diagnosis and treatment of hepatic echinococcosis. World J Hepatol. 2016; 8: 1169-81.

5. Cicek B, Parlak E, Disibeyaz S, Oguz D, Cengiz C, Sahin B. Endoscopic therapy of hepatic hydatid cyst disease in preoperative and postoperative settings. Dig Dis Sci 2007; 52: 931-5.

6. Junghanss T, da Silva AM, Horton J, Chiodini PL, Brunetti E. Clinical management of cystic echinococcosis: state of the art, problems, and perspectives. Am J Trop Med Hyg 2008; 79: 301-11.

7. Belhassen-García M, Romero-Alegria A, Velasco-Tirado V, Alonso-Sardón M, Lopez-Bernus A, Alvela-Suarez L, et al. Study of hydatidosis-attributed mortality in endemic area. PLoS One 2014; 9: e91342.

8. Manzano-Román R, Sánchez-Ovejero C, Hernández-González A, Casulli A, Siles-Lucas M. Serological Diagnosis and Follow-Up of Human Cystic Echinococcosis: A New Hope for the Future? Biomed Res Int 2015; 2015: 428205.

9. Dolay K, Akbulut S. Role of endoscopic retrograde cholangiopancreatography in the management of hepatic hydatid disease. World J Gastroenterol. 2014; 20: $15253-61$

10. Dew H. Some complications of hydatid disease. Br J Surg 1930; 18: 275-93.

11. Lewall DB, McCorkell SJ. Rupture of echinococcal cysts: diagnosis, classification, and clinical implications. AJR Am J Roentgenol 1986; 146: 391-4.

12. Ișık A, Sayar i, Gülhan B, Fırat D. Fascioliasis: A Rare Case Mimicking Cholelithiasis. South. Clin. Ist. Euras 2016; 27: 145-6.

13. Deniz Fırat113. el-Tahir MI, Omojola MF, Malatani T, al-Saigh AH, Ogunbiyi OA. Hydatid disease of the liver: evaluation of ultrasound and computed tomography. Br J Radiol 1992; 65: 390-2.

14. El Malki HO, El Mejdoubi Y, Souadka A, Mohsine R, Ifrine L, Abouqal R, et al. Predictive model of biliocystic communication in liver hydatid cysts using classification and regression tree analysis. BMC Surg 2010; 10: 16.

15. Ozaslan E, Bayraktar Y. Endoscopic therapy in the management of hepatobiliary hydatid disease. J Clin Gastroenterol 2002; 35: 160-74.

16. Kilic M, Yoldas 0 , Koc M, Keskek M, Karakose N, Ertan T, et al. Can biliary-cyst communication be predicted before surgery for hepatic hydatid disease: does size matter? Am J Surg 2008; 196: 732-5.

17. Lygidakis NJ. Diagnosis and treatment of intrabiliary rupture of hydatid cyst of the liver. Arch Surg 1983; 118: 1186-9.

18. Kumar R, Reddy SN, Thulkar S. Intrabiliary rupture of hydatid cyst: diagnosis with MRI and hepatobiliary isotope study. Br J Radiol 2002; 75: 271-4.

19. Becker K, Frieling T, Saleh A, Häussinger D. Resolution of hydatid liver cyst by spontaneous rupture into the biliary tract. J Hepatol 1997; 26: 1408-12.

20. Giouleme 0 , Nikolaidis N, Zezos P, Budas K, Katsinelos P, Vasiliadis T, et al. Treatment of complications of hepatic hydatid disease by ERCP. Gastrointest Endosc 2001; 54: 508-10. 
21. Somani SK, Srivastava AP. Resolution of hepatic hydatid cyst with biliary communication with ERCP. J Gastroint Dig Syst 2012; 2: 114.

22. al Karawi MA, Yasawy MI, el Shiekh Mohamed AR. Endoscopic management of biliary hydatid disease: report on six cases. Endoscopy 1991; 23: 278-81.

23. Akaydin M, Erozgen F, Ersoy YE, Birol S, Kaplan R. Treatment of hepatic hydatid disease complications using endoscopic retrograde cholangiopancreatography procedures. Can J Surg. 2012; 55: 244-8.

24. Zeybek N, Dede H, Balci D, Coskun AK, Ozerhan IH, Peker S, et al. Biliary fistula after treatment for hydatid disease of the liver: when to intervene. World J Gastroenterol 2013; 19: 355-61.

25. Dolay K, Akçakaya A, Soybir G, Cabioğlu N, Müslümanoğlu M, Iğci A, et al. Endoscopic sphincterotomy in the management of postoperative biliary fistula A complication of hepatic hydatid disease. Surg Endosc 2002; 16: 985-8.
26. Dawson JL, Stamatakis JD, Stringer MD, Williams R.. Surgical treatment of hepatic hydatid disease. Br J Surg 1988; 75: 946-50.

27. Bilsel Y, Bulut T, Yamaner S, Buyukuncu Y, Bugra D, Akyuz A, et al. ERCP in the diagnosis and management of complications after surgery for hepatic echinococcosis. Gastrointest Endosc 2003; 57: 210-3.

28. Inal M, Soyupak S, Akgül E, Ezici H. Percutaneous transhepatic endobiliary drainage of hepatic hydatid cyst with rupture into the biliary system: an unusual route for drainage. Cardiovasc Intervent Radiol 2002; 25: 437-9.

29. Vignote ML, Miño G, de la Mata M. de Dios JF, Gomez F. Endoscopic sphincterotomy in hepatic hydatid disease open to the biliary tree. Br J Surg 1990; 77: 30-1.

30. Spiliadis C, Georgopoulos S, Dailianas A, Konstantinidis A, Rimikis M, Skandalis $\mathrm{N}$. The use of ERCP in the study of patients with hepatic echinococcosis before and after surgical intervention. Gastrointest Endosc 1996; 43: 575-9. 